\title{
Stress in Salminus brasiliensis fingerlings due to different densities and times of transportation
}

[Estresse em alevinos de dourado (Salminus brasiliensis) em diferentes densidades e tempos de transporte]

\author{
W.B. Adamante ${ }^{1,4}$, A.P.O. Nuñer ${ }^{2 *}$, L.J.G. Barcellos ${ }^{3}$, A.B. Soso ${ }^{3}$, J.A. Finco ${ }^{3}$ \\ ${ }^{1}$ Aluno de pós-graduação - PA - UFSC \\ ${ }^{2}$ Departamento de Aqüicultura - UFSC \\ Rodovia SC 406, 3532 \\ 88066-000 - Florianópolis, SC \\ ${ }^{3} \mathrm{UPF}$ - Passo Fundo - RS \\ ${ }^{4}$ Bolsista CNPq
}

\begin{abstract}
The stress in dorado fingerlings (Salminus brasiliensis) caused by transportation at densities of 5, 10, and $15 \mathrm{~g} / \mathrm{l}$ after 4,8 , and $12 \mathrm{~h}$ was evaluated by the concentration of tissue cortisol measured by ELISA. The conditions of transportation were simulated on an orbital table shaker with horizontal movements, inside 15 litres plastic bags filled with 4 litres of water and pure oxygen. Cortisol concentrations increased in all densities after $4 \mathrm{~h}$ of transportation converging to a common concentration at the end of the tested times. Electrical conductivity of water increased with density and transportation time. The transportation caused stress on fish, but the increase on density and in times of transportation did not cause mortality to fingerlings. The transportation of $S$. brasiliensis fingerlings can be done without mortality or apparent injuries to animals until the maximum analyzed density of $15 \mathrm{~g} / \mathrm{l}$ and up to $12 \mathrm{~h}$.
\end{abstract}

Keywords: Salminus brasiliensis, fish, stress, transportation, cortisol

\section{RESUMO}

O estresse em alevinos de dourado (Salminus brasiliensis) causado pelo transporte nas densidades 5 , 10 e 15g/l após 4, 8 e 12h, foi avaliado por meio dos níveis de cortisol tecidual quantificado por ELISA. O transporte foi simulado em uma mesa agitadora com movimento orbital, em sacos plásticos de 15 litros, contendo 4 litros de água e oxigênio puro. As concentrações de cortisol aumentaram em todas as densidades após 4 de transporte e convergiram para uma mesma concentração ao final dos tempos de transporte. A condutividade elétrica da água aumentou com a densidade e com os tempos de transporte. $O$ transporte causou estresse aos peixes, mas o aumento da densidade e do tempo de transporte não causou mortalidade nos alevinos. O transporte de alevinos de $\mathrm{S}$. brasiliensis pode ser realizado até a densidade máxima avaliada de $15 \mathrm{~g} / \mathrm{l}$ e o tempo máximo de $12 \mathrm{~h}$ sem que haja mortalidade ou danos aparentes aos animais.

Palavras-chave: Salminus brasiliensis, peixe, estresse, transporte, cortisol

\section{INTRODUCTION}

The transportation of fish is done in closed systems, using plastic bags which are filled with water and pure oxygen, or in opened systems, with specific containers that receive oxygen or air (Berka, 1986).

Recebido em 29 de agosto de 2007

Aceito em 14 de abril de 2008

* Autor para correspondência (corresponding author)

E-mail: apon@cca.ufsc.br
Despite the greatest use of closed systems, the method can become a limiting factor, as well as an important stressing factor due to the accumulation of metabolites in water, as carbon dioxide and total ammonia, and also due to the decreasing of dissolved oxygen concentrations and changes of water PH (Amend et al., 1982; Berka, 1986; Gomes et al., 2003a). 
The stress produced by fish transportation is classified as acute, since it causes an increase of cortisol levels into the plasma of the animals (Barton and Iwama, 1991). Cortisol releasing is soon activated when fish feels a homeostatic change, which is triggered by several conditions that stimulate the hypothalamus-pituitaryinterrenal axis. External stimuli, caused by stressing agents, act out on hypothalamus that produces the releasing factor of corticotrophin, which acts out on the pituitary gland that, on its turn, produces adrenocorticotrophic hormone $(\mathrm{ACTH})$, that reaches the interrenal tissue in the head kidney where cortisol is released into the blood vessels (Donaldson, 1981).

To evaluate the stress caused by transportation and transferring of fingerlings, plasma or tissue concentration of cortisol had been collected from several species of fish, as Salmo trutta (Pickering, 1984), Paralichthys olivaceus (De Jesus et al., 1991), Oreochromis niloticus (Hwang et al., 1992), Seriola quinqueradiata (Sakakura et al., 1998), Salmo salar (Sandodden et al., 2001), Ictalurus punctatus (Davis et al., 2002; Bilodeau et al., 2003), Colossoma macropomum (Gomes et al. 2003a,b), and Rhamdia quelen (Barcellos et al., 2001; Barcellos et al. 2004).

According to Amend et al. (1982) and Berka (1986), the best results during transportation were achieved when fishes were submitted to a fasting of $24 \mathrm{~h}$ to promote the cleaning of digestive tract before the beginning of transportation, which avoid water quality degradation. According to these authors, the correct stocking density and time of transportation prevent the establishment of undesirable concentrations of metabolites into the water. A high density associated with a very long time of transportation can stress fish, impair transportation efficiency, and cause mortality, as well as cause negative effects on animals performance (Amend et al., 1982). Hence, an acute stress during transportation can predispose fish to pathologies after the stock-term due to immunosupression caused by stress (Barton and Iwama, 1991; Wendelaar Bonga, 1997).

Although transportation of fish is an ordinary activity at aquaculture (Carmichael et al., 2001), it is also seen as an important stressing factor (Iversen et al., 1998); but few studies had been made regarding stress on Brazilian native fish during transportation (Carneiro et al., 2002a,b; Golombieski et al., 2003; Gomes et al., 2003a,b; Urbinati et al., 2004).

This experiment studied the stress on dorado fingerlings (Salminus brasiliensis Cuvier, 1816) at different densities and times of transportation, considering this species has become important to Brazilian aquaculture.

\section{MATERIAL AND METHODS}

This trial was carried out at the Fish Culture Station of São Carlos (SC) in February 2005. S. brasiliensis fingerlings lengthing $3.75 \pm 0.53 \mathrm{~cm}$ (mean \pm standard deviation) and weighting $0.71 \pm 0.53 \mathrm{~g}$ were submitted to fast during $48 \mathrm{~h}$; then, they were stocked at a density of 5,10 , and $15 \mathrm{~g} / \mathrm{l}$, equivalent to 7,14 , and $21 \mathrm{fish} / \mathrm{l}$, respectively. The experimental units were composed by 15 litres plastic bags, with 4 litres of water and pure oxygen as the remaining part. The plastic bags were carefully closed and conditioned in a polystyrene box to avoid mechanical shocks and help on maintenance of temperature during the whole period of transportation.

The simulations of transportation were done on an orbital table shaker with horizontal movement, $40 \mathrm{~cm}$ of amplitude and 1080 cycles/h. Each density of transportation was tested during 4,8 , and $12 \mathrm{~h}$. Due to the impossibility of using the shaker simultaneously with all experimental units, this trial was carried out according to a randomized block design, with three replications that ran at different times, which constituted the blocks distributed throughout the studied times.

At the beginning of the trial and at the end of transportation, water temperature, $\mathrm{pH}$, electrical conductivity, and dissolved oxygen concentrations were measured in each experimental unit, using an YSI-55 digital oxymeter and one YSI-63 digital multiparameter. Water samples of each experimental unit were also collected for analysis of total ammonia and nitrite concentrations, according to the methodologies described by Koroleff (1976) and Golterman et al. (1978), respectively. The non-ionized ammonia fraction in water was 
calculated using Johansson and Wedborg (1980) equation.

Cortisol concentration was recorded in tissues from five fingerlings sampled in fish ponds prior the beginning of the experiment and from tissue extracted from samples of five fishes collected at each experimental unit just after the end of each transportation time. For cortisol extraction, each fish sample $(n=5)$ was pooled and the whole fishes were grinded together prior the analysis and mixed with a phosphate buffered solution (PBSG). This mixture was washed with ether, evaporated on a heated bath, and sonicated after addition of PBSG (De Jesus et al., 1991). After extraction, the concentration was determined by ELISA using the Adaltis ${ }^{\circledR}$ EIAgem-Cortisol kit.

Survival was recorded in each experimental unit at the end of time of transportation. Water quality variables, survival, and tissue cortisol concentration were analyzed by regression (Zar, 1996) to establish the relationship of each variable with transportation time at the different densities. ANOVA (Zar, 1996) was used to the compare the initial concentration of these variables at the beginning of transportation with the concentration after four hours of transportation. Each regression analysis was tested $(\alpha=0.05)$ and only valid regressions were presented as lines in the figures showed in the next pages.

\section{RESULTS AND DISCUSSION}

Temperature and $\mathrm{pH}$ of water did not show significant differences $(\mathrm{P}>0.05)$ among densities and times of transportation, presenting mean values ( \pm standard error) of $20.6 \pm 0.8^{\circ} \mathrm{C}$ and $6.8 \pm 0.1$. The dissolved oxygen concentration in water at the end of each time always remained above $20 \mathrm{mg} / \mathrm{l}$ in all the experimental units, exceeding oxymeter capacity, indicating a supersaturation of gas into the water.

At the beginning of this trial, total ammonia concentration was not present in the water; however, the concentrations showed significant increase $(\mathrm{P}<0.05)$ along the time at the $10 \mathrm{~g} / \mathrm{l}$ density (Fig. 1a). The low total ammonia concentration, registered at $5 \mathrm{~g} / \mathrm{l}$, did not change with time and the same happened at $15 \mathrm{~g} / \mathrm{l}$ density, in which the highest concentrations were registered after the first four hours of transportation. The lowest density did not produce ammonia to alter its concentration in water, but with the double of biomass $(10 \mathrm{~g} / \mathrm{l})$ the concentration increase was noticeable. The nonionized ammonia concentrations in water always remained below $0.01 \mathrm{mg} / \mathrm{l}$ and probably did not stress fish, once concentrations below $0.02 \mathrm{mg} / 1$ were considered safe for the majority of fish species (Vinatea, 1997; Baldisserotto, 2002; Foss et al., 2003). The presence of nitrite in water was not detected at the initial readings, but its concentration increased $(\mathrm{P}<0.05)$ during transportation at 5 and $10 \mathrm{~g} / 1$ densities, whereas the concentrations found at $15 \mathrm{~g} / 1$ remained high during all times of transportation (Fig. 1b).

At the beginning of transportation, the electrical conductivity of water $\left(14.0 \pm 1.7 \mu \mathrm{Scm}^{-1}\right)$ increased significantly $(\mathrm{P}<0.05)$ during the first four hours in all densities. After that, it remained constant at 5 and $15 \mathrm{~g} / 1$ densities and there was a significant increase $(\mathrm{P}<0.05)$ with time at the $10 \mathrm{~g} / \mathrm{l}$ density (Fig. 2). The increase of water conductivity in the experimental units was caused by ions release, mainly $\mathrm{Na}^{+}$and $\mathrm{K}^{+}$, through gills, since fish presented exchanges on osmoregulation during stressing conditions (Wendelaar Bonga, 1997).

The mean concentration of cortisol ( \pm standard deviation) on tissue of $S$. brasiliensis fingerlings at the beginning of transportation was $45.0 \pm 21.2 \mathrm{ng} / \mathrm{mg}$, a value lower $(\mathrm{P}<0.05)$ than the one registered at all tested densities after 4 hours of transportation, which were on average four times superior to the initial value. Later, cortisol concentrations stayed high at 15 and $10 \mathrm{~g} / \mathrm{l}$ densities, but decreased at the lowest density (Fig. 3).

The initial increase of cortisol concentration was also registered by Gomes et al. (2003a) in the transportation of Colossoma macropomum juveniles at different densities; however, concentration decreased as time passed by and when submitted to a period of recovery. After the first four hours of transportation, it was recorded an increase of cortisol for Salmo salar (Sandodden et al., 2001) and Perca fluviatilis (Acerete et al., 2004), when they were under stress due to transportation. 
a)

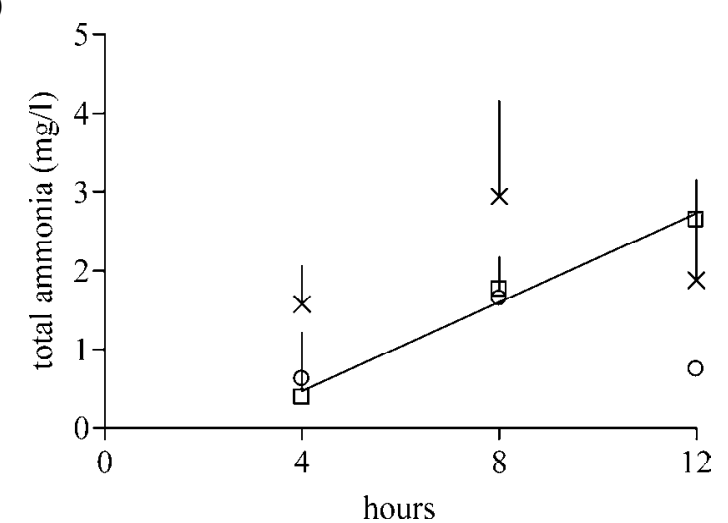

b)

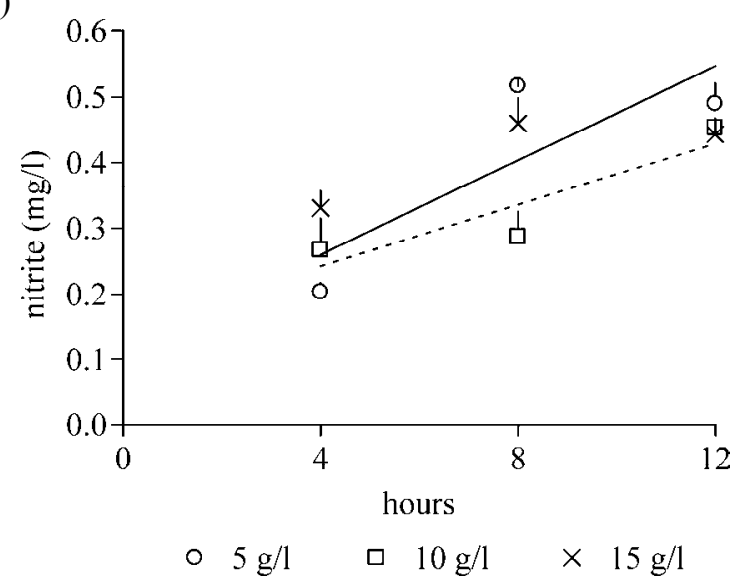

Figure 1. Total ammonia (a) and nitrite (b) concentrations (mean \pm standard error) in water during transportation of $S$. brasiliensis fingerlings in three times and densities. (a) filled line indicates regression between total ammonia and time at the density $10 \mathrm{~g} / \mathrm{l}$; (b) filled line indicates regression between nitrate and time at the density $5 \mathrm{~g} / \mathrm{l}$ and dotted line at the density $10 \mathrm{~g} / \mathrm{l}$.

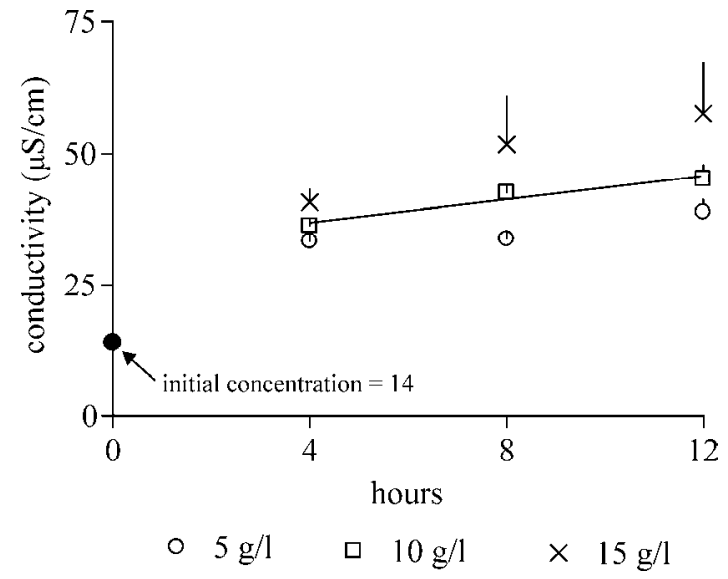

Figure 2. Conductivity (mean \pm standard error) of water during transportation of $S$. brasiliensis fingerlings in three times and densities. Filled line indicates regression between conductivity and time at the density $10 \mathrm{~g} / 1$. 


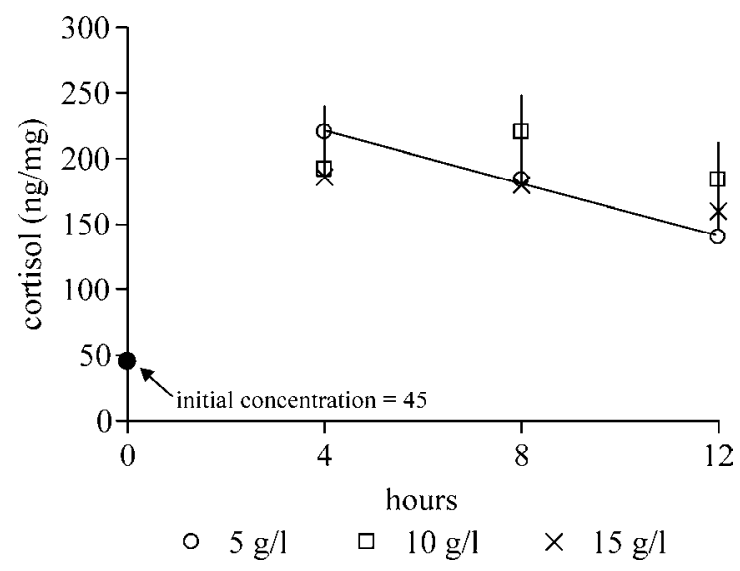

Figure 3. Cortisol concentrations (mean \pm standard error) in tissue of $S$. brasiliensis during transportation of $S$. brasiliensis fingerlings in three times and densities. Filled line indicates regression between cortisol and time at the density $5 \mathrm{~g} / 1$.

The inverse relation among cortisol concentrations and density of transportation along the time were observed in Brycon cephalus fingerlings under stress transportation (Urbinati et al., 2004). Robertson et al. (1988) analyzed the plasmatic cortisol variation in Sciaenops ocellatus juveniles during transportation in water with $32 \%$ of salinity and registered the increase in cortisol levels after $1 \mathrm{~h} 30 \mathrm{~min}$, when compared to the initial concentration. After $5 \mathrm{~h} 30 \mathrm{~min}$, fish were transferred to recovery tanks and, after two days, concentrations decreased to values next to the initial ones. These authors also tested the $2 \mathrm{~h}$ $30 \mathrm{~min}$ time of transportation in 4\%o salinity water and observed that, after $30 \mathrm{~min}$, the plasmatic cortisol increased from almost zero to $150 \mathrm{ng} / \mathrm{ml}$, decreasing at the end of the trial to values near to $50 \mathrm{ng} / \mathrm{ml}$. According to Barcellos et al. (2001), the increase of plasmatic cortisol in Rhamdia quelen happened one hour after its transference to growing tanks, which could explain the fast effect registered in this study.

S. brasiliensis fingerlings were evaluated until the end of transportation times, since cortisol was not recorded during the recovering period, even though a reduction in concentration to levels near basal ones was expected. Nevertheless, after 8 and $12 \mathrm{~h}$ of transportation, the reduction of cortisol concentrations showed the same pattern already observed by Barcellos et al. (2001) after 4,12 , and $24 \mathrm{~h}$, despite there was a different response concerning the duration of the stressing stimulation.
After the initial increase, cortisol concentrations from different densities converged to a common value at the end of the tested times of transportation $(\mathrm{P}<0.05)$. These variation presented similarity to the standard response to other stimuli that cause acute stress, which tended to return to basal levels after the initial increase.

The densities and times of transportation produced stress on $S$. brasiliensis fingerlings but did not cause mortality, suggesting that conditions that could compromise the survival of fingerlings are beyond the tested levels. Therefore, until the maximum analyzed density of $15 \mathrm{~g} / \mathrm{l}$ and time of $12 \mathrm{~h}$, the transportation of $S$. brasiliensis fingerlings can be done without mortality or apparent injuries to animals.

\section{ACKNOWLEDGMENTS}

The authors thank the Conselho Nacional de Pesquisa e Desenvolvimento (CNPq/Brazil) for the scholarship given to the first author and Tractebel Energy for the financial support.

\section{REFERENCES}

ACERETE, L.; BALASCH, J.C.; ESPINOSA, E. et al. Physiological responses in Eurasian Perch (Perca fluviatilis) subjected to stress to transport and handling. Aquaculture, v.237, p.167-178, 2004.

AMEND, N.F.; CROV, T.R.; GOVEN, B.A. et al. Transportation of fish in closed systems: 
methods to control ammonia, carbon dioxide, $\mathrm{pH}$ and bacterial growth. Trans. Am. Fish Soc., v.11, p.603-611, 1982.

BALDISSEROTTO, B. Fisiologia de peixes aplicada à piscicultura. Santa Maria: Editora da UFSM, 2002. 212p.

BARCELLOS, L.G.; KREUTZ, L.C.; QUEVEDO, R.M. et al. Nursery rearing of jundiá, Rhamdia quelen (Quoy \& Gaimard), in cages: cage type, stocking density and stress response to confinement. Aquaculture, v.232, p.383-394, 2004.

BARCELLOS, L.G.; WOEHL, V.M.; WASSERMANN, G.F. et al. Plasma levels of cortisol and glucose in response to capture and tank transference in Rhamdia quelen (Quoy \& Gaimard), a South American catfish. Aquac. Res., v.32, p.121-123, 2001.

BARTON, B.A.; IWAMA, G.K. Physiological changes in fish from stress in aquaculture with emphasis on the response and effects of corticosteroids. Annu. Rev. Fish Dis., v.1, p.3-26, 1991.

BERKA, R. The transport of live fish: a review. Rome: FAO, 1986. 57p. (EIFAC Technical Papers, 48).

BILODEAU, A.L.; SMALL, B.C.; WOLTERS, W.R. Pathogen loads, clearance and plasma cortisol response in channel catfish, Ictalurus punctatus (Rafinesque), following challenge with Edwardsiella ictaluri. J. Fish Dis., v.26, p.433437,2003

CARMICHAEL, G.J.; TOMASSO, J.R.; SCHEDLER, T.E. Fish transportation. In: WEDEMEYER, G.A. (Ed). Fish hatchery management 2.ed. Bethesda: American Fisheries Society, 2001, p.641-660.

CARNEIRO, P.C.F.; MARTINS, M.L.; URBINATI, E.C. Effect of sodium chloride on physiological responses and the gill parasite, Piscinoodinium sp., in matrinxã, Brycon cephalus, (Teleostei: Characidae) subjected to transport stress. J. Aquac. Trop., v.17, p.337-348, 2002a.

CARNEIRO, P.C.F.; URBINATI, E.C.; MARTINS, M.L. Transport with different benzocaine concentrations and its consequences on hematological parameter and gill parasite population of matrinxã, Brycon cephalus
(Günther, 1869) (Osteichthyes, Characidae). Acta Scient., v.24, p.555-560, 2002 b.

DAVIS, K.B.; GRIFFIN, B.R.; GRAY, W.L. Effect of handling stress on susceptibility of channel catfish Ictalurus punctatus to Ichthyophthirius multifiliis and channel catfish virus infection. Aquaculture, v.214, p.55-66, 2002.

DE JESUS, E.G.; HIRANO, T.; INUI, Y. Changes in cortisol and thyroid hormone concentrations during early development and metamorphosis in the Japanese flounder, Paralichthys olivaceus. Gen. Comp. Endocrinol., v.82, p.369-376, 1991

DONALDSON, E.M. The pituitary-interrenal axis as an indicator of stress in fish. In PICKERING, A.D. (Ed). Stress and fish. London: Academic Press, 1981. p.11-47.

FOSS, A.; EVENSEN, T.H.; VOLLEN T. et al. Effects of chronic ammonia exposure on growth and food conversion efficiency in juvenile spotted wolfish. Aquaculture, v.228, p.215-224, 2003.

GOLOMBIESKI, J.I.; SILVA, L.V.F.; BALDISSEROTTO, B. et al. Transport of silver catfish (Rhamdia quelen) fingerlings at different times, load densities, and temperatures. Aquaculture, v.216, p.95-102, 2003.

GOLTERMAN, H.L.; CLYMO, R.S.; OHNSTAD, M.A.M. Methods for chemical analysis of freshwater. Oxford: Blackwell Scientific Publications, 1978. 213p.

GOMES, L.C.; ARAÚJO-LIMA, C.A.R.M.; ROUBACH, R. et al. Effect of fish density during transportation on stress and mortality of juvenile tambaqui Colossoma macropomum. J. World Aquac. Soc., v.34, p.76-84, 2003 a.

GOMES, L.C.; ARAÚJO-LIMA, C.A.R.M.; ROUBACH, R. et al. Avaliação dos efeitos da adição de sal e da densidade no transporte de tambaqui. Pesq. Agrop. Bras., v.38, p.283-290, 2003b.

HWANG, P.P.; WU, S.M.; LIN, J.H. et al. Cortisol content of eggs and larvae of teleosts. Gen. Comp. Endocrinol., v. 86, p. 189-196, 1992.

IVERSEN, M.; FINSTAD, B.; NILSSEN, K.J. Recovery from loading and transport stress in Atlantic salmon (Salmo salar L.) smolts. 
Aquaculture, v.168, p.387-394, 1998.

JOHANSSON, O.; WEDBORG, M. The ammonia-ammonium equilibrium in seawater at temperatures between 5 and $25^{\circ}$ C. J. Sol. Chem., v.9, p. 37-44, 1980.

KOROLEFF, F. Determination of ammonia In: GRASSHOFF, K.; EHRDART, M.; KREMLING, K. (Eds). Methods of seawater analyses. Weinheim: Verlag Chemie, 1976. p.126-133.

PICKERING, A.D. Cortisol-induced lymphocitopenia in brown trout, Salmo trutta L., Gen. Comp. Endocrinol., v.53, p.252-259, 1984.

ROBERTSON, L.; THOMAS, P.; ARNOLD C.R., Plasma cortisol and secondary stress responses of cultured Red Drum (Sciaenops ocellatus) to several transportation procedures. Aquaculture, v.68, p.115-130, 1988.

SAKAKURA, Y.; TAGAWA, M.; TSUKAMOTO, K. Whole-body cortisol concentrations and ontogeny of aggressive behavior in yellowtail (Seriola quinqueradiata Temminck \& Schlegel, Carangidae). Gen. Comp. Endocrinol., v.109, p.286-282, 1998.

SANDODDEN, R.; FINSTAD, B.; IVERSEN, M. Transport stress in Atlantic salmon (Salmo salar): anesthesia and recovery. Aquac. Res., v.32, p.87-90, 2001.

URBINATI, E.C.; ABREU, J.S.; CAMARGO, A.C.S. et al. Loading and transport stress in juvenile matrinxã (Brycon cephalus, Characidae) at various densities. Aquaculture, v.229, p.389400, 2004.

VINATEA, L.A. Princípios químicos de qualidade de água em aqüicultura: uma revisão para peixes e camarões. Florianópolis: Editora da UFSC, 1997. 166p.

WENDELAAR BONGA, S.E. The stress response in fish. Physiol. Rev., v.87, p.591-625, 1997.

ZAR, J.H. Biostatistical analysis. 3.ed. New Jersey: Prentice Hall, 1996. 662p. 